\title{
Communication
}

\section{Climate Dialog, Climate Action: Can democracy do the job?}

\author{
Fred Phillips ${ }^{1 *}$, LaVonne Reimer ${ }^{2}$ and Rebecca Turner ${ }^{3,}$ \\ 1 Tongji University; fred.phillips@stonybrook.edu \\ 2 Descant Labs; lreimer@descantlabs.com \\ 3 Turner Consulting Group LLC; becky@turnerconsulting.com \\ * Correspondence: phillipsf@unm.edu; Tel.: +1 5127587840
}

\begin{abstract}
The latest IPCC report forcefully states that immediate, decisive, and large-scale actions are needed to avert climate catastrophe. This essay presumes that democratic governments are best and most desirably positioned to take these actions. Yet in the countries most pivotal to global climate, significant voting blocs are uninterested in environmental issues. The essay urges adding bottom-up dialog between environmental and anti-environmental voters, to current and future top-down technocratic "solutions." To make this combination result in a unified pro-environment electorate, we must understand: religious objections to environmentalism; the capital-vs.-knowledge strife that slows polluting corporations' green transitions; and the psychological mechanisms that can make inter-group dialog fruitful.
\end{abstract}

Keywords: climate; democracy; religion; evangelism; environment

\section{Introduction: Bad news, good news, and overcoming 'problem/solution'}

Can democracy, with its slow and plodding processes, avert global eco-catastrophe? We hope so. The alternative - relying on an unaccountable authoritarian government to help us survive extreme climate change - would be foolish, like jumping from the fire into the frying pan.

Scientists believe perilous climate change is already upon us, and that it is irreversible and worsening quickly. Scientific and religious orientations toward climate are at odds, with some sects even welcoming world-ending eco-doom, equating it with the Second Coming of Christ ${ }^{1}$. The behavior of polluting corporations does not impress. Even as climate solutions depend on newer and newer technologies, the knowledge workers who can create the technologies find themselves at odds with corporate owners.

That's the bad news. The good news is that people still harbor goodwill toward fellow humans.

A few countries, for example the United States and Brazil, are pivotal to the climate problem, either because of their industries or their natural resources. Yet these same countries sport influential blocs of anti-environmental sentiment, motivated by economy or religion.

Getting anti-environmental voters to support pro-climate laws, treaties and actions depends on overcoming an us-versus-them mentality, understanding the others' perspectives, and reaching a shared view of the future. A difficult undertaking, and an urgent one.

Avoiding a dim scenario for humanity's future depends on aligning democracies' electorates by finding common cause among them. It depends on overcoming a purely problem/solution perspective, augmenting it with a dialog-plus-shared-vision approach.

\section{When the catastrophe?}

${ }^{1}$ See references at https://en.m.wikipedia.org/wiki/Rapture. 
Preachers' predictions of the timing of apocalypse and the Second Coming have been recurrent, and to date, unexceptionally wrong. Scientists' specific warnings of eco-catastrophe can be wrong, too, the most famous example being biologist Paul Ehrlich's failure ${ }^{2}$ to account for innovations that stretch resources.

No scientist now predicts the "end of the world." Rather, researchers predict specific climatic conditions that will give rise to specific human hardships.

The United Nations' Intergovernmental Panel on Climate Change (IPCC) reports a consensus of 90 climate scientists from 40 countries that if we do not limit global warming to 1.5 degrees Celsius by 2040, there will be so much heat-trapping carbon in the atmosphere that the warming will be irreversible. "Extreme droughts, devastating wildfires, massive floods, deadly hurricanes, and widespread famines" will become the norm [1]. The IPCC says meeting this global temperature goal requires cutting $\mathrm{CO} 2$ emissions by $45 \%$ by 2030 . The agency's August, 2021 report $^{3}$ forcefully underlines the urgency of the challenge.

Paúl [2] predicts "dramatic" increases in flooding of coastal cities due to tidal and climate change effects - up from 20 days/year to as much as 75. H.J. Schellnhuber of the Potsdam Climate Institute anticipates up to one million species could be lost in coming decades" [3].

As politicians haggle over specific rules for the Paris Accords, which will be non-binding in any event, the Australian Breakthrough National Centre for Climate Restoration foresees

world governments "politely ignoring" the advice of scientists and the will of the public to decarbonize the economy... resulting in a global temperature increase $5.4 \mathrm{~F}$ (3C) by the year 2050. At this point, the world's ice sheets vanish; brutal droughts kill many of the trees in the Amazon rainforest (removing one of the world's largest carbon offsets); and the planet plunges into a feedback loop of ever-hotter, ever-deadlier conditions.

$35 \%$ of the global land area, and $55 \%$ of the global population, are subject to more than 20 days a year of lethal heat conditions, beyond the threshold of human survivability. Meanwhile... nearly one-third of the world's land surface turns to desert. Entire ecosystems collapse, beginning with the planet's coral reefs, the rainforest and the Arctic ice sheets. The world's tropics are hit hardest by these new climate extremes, destroying the region's agriculture and turning more than 1 billion people into refugees" [4].

\section{Science and religion}

Hal Linstone, founding editor of the journal Technological Forecasting \& Social Change, championed multiple-perspective approaches to complex problems. Early in this century he expanded his T-O-P (technical, organizational, and personal) set of frames to PORT, adding $\mathrm{R}$ for religious perspectives. He had in mind the motivations of religious extremists in the mid-east, which though frequently reprehensible could at least be understood as manifestations of our own darker selves.

The $\mathrm{R}$ perspective is even more pertinent in 2021, though much less comprehensible to many. Our own audiences [5] outside the U.S. and other strongholds of evangelism find the "rapture" idea simply too bizarre to grasp, and are equally baffled that a dangerously large portion of the US electorate embraces the idea and consequently doesn't concern itself with the quality of the Earthly environment its adherents will (soon, they hope) leave behind.

\footnotetext{
${ }^{2}$ https://www.nytimes.com/2015/06/01/us/the-unrealized-horrors-of-population-explosion.html

${ }^{3}$ https://www.ipcc.ch/report/ar6/wg1/
} 
The number of Americans self-identifying as evangelical is shrinking ${ }^{4}$. It is growing in Latin America [6] and, according to The Economist [7], in Ireland. The U.S. trend is offset by the startling growth of the New Apostolic Reformation, a growing Christian movement that is nondenominational, openly political, and views the climate-change denier Donald Trump as God's chosen president [8].

Both environmentalists and the religious right believe world-changing events will soon come to pass. One camp regards the events as threats; the other as promises. Recent years have seen worsening polarization of the two groups.

\section{The knowledge society}

We must consider these trends and warnings in conjunction with the ascent of the knowledge economy, as it was described by Drucker, Nonaka, and even Karl Marx. Its essence is that knowledge will replace capital as the most important factor of production. The near-inevitable shift to a knowledge society progresses slowly. It generates the expected pushback from those with something to lose, namely those who have more dollars than sense - and fear capital's loss of power.

Apple employees, for example, are agitating for flexible work arrangements, even as management insists on a full time return to the cubicles [9]. The remarkable thing is not what the (non-unionized) employees are demanding, but rather the fact that they can make demands, knowing Apple's biggest HR problem is finding qualified knowledge workers.

Apple managers may be correct that collocation leads to greater productivity. Yet it is the educated who, in the richer countries, are the most ardent environmentalists. In a fully realized knowledge economy, knowledge workers would force employers toward more environmentally responsible actions. Though knowledge workers are capable of networking themselves remotely, collocation means increased incidental communication among them, and consequently, greater risk that they gain the upper hand over managers and stockholders.

The Gallup Polls define Concerned Believers as those who "are highly worried about global warming, think it will pose a serious threat in their lifetime, believe it's the result of human activity, and think news reports about it are accurate or underestimate the problem." Gallup dubs those not fitting that definition as "skeptics" or "unconvinced." Concerned Believers are the majority among: 18-to-29 year olds; women; those with college or postgrad degrees; non-Whites; and the politically liberal and moderate [10].

\section{Corporate behavior}

At the time of the first Earth Day, 50 years ago, CEOs' ignorance of environmental matters could be excused. Current CEOs, who can claim no such excuse, may hope to generate impressive shareholder returns and retire before the more painful effects of climate change manifest themselves. However, says Rachel Bronson ${ }^{5}$, CEO of the Bulletin of the Atomic Scientists, these effects "are happening faster than scientists predicted." Despite what a slim majority of executives believe (see inset below), there can be no more short-term/long-term distinction. The long term is upon us now, and CEOs must poop or get off the potty.

Of the United States' top 100 companies, only $40 \%$ lobby lawmakers at the state and federal level for climate-friendly legislation, despite setting lofty sustainability goals.

$76 \%$ of [all U.S.] companies have said publicly they believe in climate science and $92 \%$ have said they plan to make their operations greener with sustainability

\footnotetext{
4 https://www.prri.org/research/2020-census-of-american-religion/\#page-section-0

5 in an email, $7 / 22 / 21$.
} 
and emissions reduction goals. Meanwhile, 20 of the [same] companies have lobbied against climate-friendly policies in the last five years.

$51 \%$ see policies and legislation that address climate change as a short-term financial risk, even as $74 \%$ say they believe climate change will threaten their assets long-term [11].

These sad statistics reflect corporate short-termism [5], greenwashing ${ }^{6}$, outsourcing of the manufacturing steps that involve pollution or child labor [12], and empty promises. As an example of the latter, "Amazon, Microsoft, and PepsiCo are just a few of the $100+$ businesses turning climate crisis into climate action by committing to reach net zero carbon emissions by 2040,"7 though this "commitment" is non-contractual and carries no penalties for non-performance.

Attorney and author Paul Levine [13] has his fictional character Jake Lassiter complain that oil companies" "computer models tell them how many tankers will cruise the Gulf [of Mexico] before one strikes a reef and [what tonnage] will ooze into the precious estuaries." The companies are insured for exactly this precisely foreseen risk, but are ever "ready to fax prepackaged news releases that explain the company's profound concern at this unanticipated and unfortunate incident."

\section{Scenario}

Price [14] fleshes out a depressing scenario ${ }^{8}$ that is all too consistent with the information presented above. Fifty years from now, climate change is obvious to everyone, and denial is passé. Wealth disparities are more extreme, giving capitalists enough clout to halt the knowledge economy transition.

Less affluent, less morally upright knowledge workers are "bought out," to serve and maintain the enclaves of the wealthy, in return for a life of material comfort - but a life of high anxiety, as the price of displeasing their masters is sudden descent into toxic poverty. The remainder of the techies are left to their own devices, so to speak, on a resource base that is mostly desert - lands ruined after ecological collapse or regional nuclear conflicts. Alternatively, they join the uneducated proletariat in squalid conditions, occupying themselves by synthesizing pseudo-foods that are not conducive to long life.

Varied religious beliefs proliferate, but if any are evangelical, they must be of the post-millennialist variety: Hell has arrived on Earth in advance of a messiah.

In this scenario, some of the extreme wealth belongs to nouveau-riche tech entrepreneurs, who feel ambivalent about whether to identify with the super-rich or with the intelligentsia. Those who take the latter route are frozen out of the wealthy folks' strategy of pulling a bigger share of the Earth's shrinking resources into their residential redoubts. The dissenting entrepreneurs turn to support other disaffected knowledge workers' weak attempts to build eco-friendly communities on the despoiled lands - and to kill or sabotage the "growther" plutocrats.

The armed-guard business is one of the growthiest of the growth industries.

\section{Constructive engagement}

That scenario's plausibility depends on lasting enmity between the "greedy" and the eco-reformers. (We place "greedy" in quotation marks because as shall be seen, much depends on each side's perception of the other.) Its plausibility is enhanced by the news [15] that "people like Peter Thiel and several cryptocurrency millionaires have already started buying up property and building bunkers in New Zealand" and that [16] the

\footnotetext{
6 "convey[ing] a false impression that a company or its products are environmentally sound." https://www.investopedia.com/terms/g/greenwashing.asp

7 https://www.facebook.com/theclimatepledge/posts/194000676065204

8 sketched in outline by a number of earlier sci-fi writers, notably Poul Anderson and Harry Harrison.
} 
USA's "path to political influence involves defecting from your hometown and congregating in one of a handful of wealthy neighborhoods. It's undermining trust in government and corroding our democracy." Also undermining trust is the philanthropy of the super-rich, which while undoubtedly doing some good, resembles performance art (see e.g., [17]) rather than well-informed investment in our future.

The above scenario also highlights the actors in the drama, and the gaps between groups of actors:c survivalists and ameliorists; individualists and communitarians; capital and knowledge; rich and poor; and purveyors and consumers of misinformation vs. people devoted to peer-reviewed evidence. Because top-down, technocratic measures have so far shown only limited success in lessening the climate crisis, we turn to a number of psychological theories and show how these offer possible bottom-up alternatives. These alternatives can help close the gaps among actor groups, bringing us closer to a unified environmentalist electorate. We'll concentrate here on the evangelical-environmentalist gap. Narrowing it will have positive halo effects on some of the other gaps.

Some of these alternatives have already shown success, and none show a potential for harm. Below, we show by example that matching one view against another in the public media fails to improve the situation, and likewise a purely economic argument fails. We then move on to the psychological possibilities.

\subsection{Two approaches that alone won't do the job}

Two approaches to persuading the religious have not worked. One of these is to match one scriptural story against another. White people offended by the Black Lives Matter movement declared, "All lives matter - why focus on Black lives?" One scholar ${ }^{9}$ noted that Jesus, asked why, in a world of suffering, he urged aid to one group rather than another, replied, "Because they're the ones who need it most, right now." The scholar's comment had zero impact on the debate.

Nobel laureate William Nordhaus [18] writes that the Kyoto Protocols did not work, and nor will the Paris Agreement, because of the free-rider problem: Each country hopes the others will reduce carbon emissions so they won't have to. Nordhaus urges penalties for nations that do not participate in international climate treaties. His "solution" is compulsory membership in an incentive structure.

This is worth trying. Yet Nordhaus is stuck in a problem/solution mode, different from the "finding common ground" mode we urge here. In addition, democratic countries must vote to join his incentive club. That will not happen without the prior groundwork described below. Furthermore, the EU's carbon import rules may ensure that other countries do reduce $\mathrm{CO} 2$.

\subsection{Diffusion of responsibility theory}

Diffusion of responsibility encompasses the economic free-rider problem, but is more forward-looking and comprehensive. Originally this social psychology theory referred to a situation in which many bystanders witness an emergency but no one does anything, because they all assume it is not their role and somebody else will take care of it [19] (see also [20]). Diffusion of responsibility refers to the tendency to subjectively divide the personal responsibility to help by the number of bystanders present.

The theory includes two corollaries: evaluation apprehension (fear of being judged); and (iii) pluralistic ignorance (aka "consensus trance," relying on the others' reactions or non-reactions when apprehending an ambiguous event). The theory thus offers openings in dealing with those who are religiously disinclined to environmentalism:

- Just as hospitals now offer discreet rooms for vaccinating vocal anti-vaxxers who are hedging their bets, millennialists may be reminded that the ballot box is secret.

${ }_{9}$ Not the present authors. 
- $\quad$ The young are initially immune to consensus trance. Indeed it is younger evangelicals who have become skeptical or apostate. To the extent that the young are social media users and potential network influencers, they are promising initial interlocutors on climate change issues.

We do not advocate cynical public relations campaigns, but rather dialog that respects where the evangelical is coming from. However, new sects are arising - the New Apostolic is an example - and a mischievous mind cannot but see the option of starting and promulgating still another new one, one with a more benign interpretation of the Book of Revelations [21].

\subsection{Appreciative inquiry}

When "the majority of Republicans think the 2020 U.S. election was stolen, and almost half of independents either think the election was rigged or are unsure" [22], and both groups are susceptible to similar disinformation about environmental matters, it makes little sense to further offend them by calling their views a "problem." Doing so would only take us farther from any possible solution.

If instead we apply the principles of appreciative inquiry [23], we may focus on what the religious right and eco-reformers have in common, and on what both groups can agree upon as a vision of the future. To begin, we jettison the term "concerned believer" due to possible confusion between "belief" in dangerous climate change, on the one hand, and religious belief, on the other.

We hopefully presume that environmentalists value evidence above faith. We presume further that if many environmentalists are not particularly religious themselves, they nonetheless respect the religious impulse. (The present authors place ourselves in this group.) This gives us our first point of commonality with the New Apostolic Reformation and the unaffiliated evangelical congregations: The traditional sects have not satisfied either of us.

Next, we allow that people who want to believe in a supreme father are not just suffering "daddy issues." They know the world offers mysteries beyond our current comprehension, and they embody all mysteries in the person of an omnipotent God. Scientists, too, acknowledge there are mysteries (e.g., [24]), and hope science will eventually solve them. Both groups admit mysteries; one looks for their resolution in the mind of God, and the other looks for them in scientific cosmogeny.

For guidance on appreciative inquiry procedures and dialogs, see https://positivepsychology.com/appreciative-inquiry-process/.

\subsection{In-group theory}

Appreciative inquiry is feasible to build what people have in common but difficult here due to the polarization of views and viewing the other in extreme terms, as suggested by in-group and out-group theory [25]. This theory is easily comprehended by thinking of a college fraternity: It's difficult to get in, full membership is preceded by ritual challenges (hazing, in the case of frats), members defend each other even when their actions are indefensible, and outsiders are dissed.

In related work, Moscovici [26] (also [27]) studied how (opinion) minorities can influence (opinion) majorities in a group setting. Most importantly, the minority member must be consistent in their opinion, have confidence in the correctness of their position, appear to be unbiased and resist social pressure and abuse. They need to propose a clear position.

Takeaways from these ideas:

- Dialog takes on a different character in individual conversations and in group discussion.

- Environmentalists are at an initial disadvantage on the consistency dimension, because faith is constant but science changes as new knowledge is gained. This was 
amply illustrated in Covid-19 countermeasure discussions, with Dr. Fauci and the CDC on one side and anti-maskers on the other.

- Avoid confronting "their facts" with "our facts." With few exceptions, this approach has proven fruitless. Strive for commonality of views and opinions.

\subsection{Action learning teams}

An approach that seems promising is "action learning teams". These date back to the 1960s and 1970s and has been associated with work by Kurt Lewin and Reg Revans at the National Training Laboratories. One of the present authors uses this technique to help groups solve complex problems. It is effective in creating empathy and trust in groups that feature diverse views. The approach is detailed in Marquardt et al. [28].

\subsection{Attractor narratives}

Scientists do celebrate the raising of new questions. This trait is shared by some religious groups, Talmudists for example, but is abhorred by fundamentalists who stick to "literal" reading of scripture. This is despite that some interpretation is unavoidable even if only in the translation of scripture from Aramaic or Greek to English.

People reflexively and comfortably look to archetypal stories (and their supposed morals) for guidance on current problems. The Covid pandemic, making a near perfect storm in conjunction with 2021's wildfires, migrant crises, and stronger hurricanes, brings to mind the Plagues of Egypt. The climate crisis, to the extent it is acknowledged, harks back to Noah and the flood. The Noah story's subplot, that wicked humans were not issued cruise tickets, jibes with the evangelical idea that those not born again will not be raptured to heaven.

Unfortunately, this reflex limits one's scope of responses. Noah saw his job as building and populating the ark; he did not consider how to prevent the flood. Some scientists share Noah's inclination: Those building the seed vault in Svalbard, Norway ${ }^{10}$ hope to preserve the genomes of all known plant life, against a species' extinction in agriculture or in the wild. Likewise it's not just for giggles that geneticists hope to revive the extinct wooly mammoth [29]; they are refining techniques that could, post-catastrophe, bring back living species currently at risk of extinction from climate change. ${ }^{11}$

In these early Old Testament chapters, humans either obeyed God or did not. It is only in later chapters that we started arguing with God. It falls to scientists of an argumentative personality to prevent or minimize eco-disaster, rather than take it as a given and plan only for survival or adaptation. Yet to make the above psychological measures work, they must hold argumentation in check.

Not that we should stop trying problem-solution approaches and appeals to logic. But these have not moved anti-environmentalists to date. Applicable psychology principles should be added to the mix.

\section{Not the end}

There are two parts to the evangelical logic. One, that the born-again will be raised to heaven. Two, that the rest of us will at best simply be left behind and at worst suffer damnation and the end of the world. We might hope evangelicals consider the first part to be of primary importance. To feel glee (or even indifference) at the supposed subsequent suffering of the rest of humanity would be unbecoming the dignity of their religion and its injunction to "love they neighbor." The more neighborly avenue would be to help us build a good home on Earth - a kind of barn-raising. It is encouraging that South Ko-

\footnotetext{
${ }^{10} \mathrm{https} / / /$ www.seedvault.no/

11 This brings to mind the two unicorns watching from shore as the ark departs. One says to the other, "Oh darn, that was today?"
} 
rean evangelism, for example, emphasizes salvation, health and prosperity in the here and now [30], attaching little or no importance to apocalypse and rapture.

And after all, whether we believe climate change is natural, man-made, or God's punishment, we are all left with the same question: What shall we do about it?

\subsection{Is this practical?}

We have tried to find ways to establish points of commonality between environmentalists and the millennialist evangelicals and others who represent a formidable anti-environmental voting bloc. It's then necessary to build on the commonalities to create a vision of the future. Avoiding Price's grim scenario depends on overcoming communication and motivation gaps, but it also depends on green industry quickly providing enough wealth to go around.12 A positive shared future will be one in which the actor groups join forces to change the balance of economic power [31], so that concerned individuals can vote and invest in their best interests.

We concluded with an admittedly wishful start toward this. Its fulfillment will need dialog across ideological fences, and much research on the part of psychologists and sociologists. Rapprochement plans can always be accused of Pollyanna-ism, and - as not all evangelicals believe in the rapture, and evangelicalism is so confounded with politics that even believers are confused ${ }^{13}$ - full reconciliation will need a more multi-faceted plan than the one presented here.

Yet two bits of research point to the plausibility of what we are suggesting. Anglin [32] finds that although "research on belief perseverance often suggests that people maintain or even strengthen their beliefs in response to disconfirming evidence" evidence and logic can under certain conditions cause true believers' beliefs to evolve. Keohane [33] shows that appreciative inquiry can get Republicans and Democrats to see each other not as caricatures but as fully human beings. We may hope for similar success with environmentalists and religious climate-deniers.

\subsection{Now, about those corporations}

Meanwhile, among the corporations whose misbehavior is documented above, just 100 firms are responsible for $71 \%$ of global emissions [34], and 20 account for the most ocean pollution [35]. Readers concerned about climate change might - in addition to compassionate outreach to anti-environmental voters - consider direct consumer action, urging congressional representatives to tighten the screws on these corporations, and utilizing the information and resources in the Riley and Young articles.

\subsection{Making democracy work for Earth}

Will democracies ease climate change, or will this task fall to coercive governments that lack accountability? With the possible (and then, only intermittent) exception of China, 21st-century autocracies have been anti-environmental. For this reason, this essay urges dialog within democracies, leading to voters' push toward environmental action.

If successful, change in voter sentiment will not save all lives and all homes. Some countries have promised zero emissions by 2050 or 2060, not realizing the dynamics of the matter - i.e., worsening conditions between now and then - will draw off resources needed to meet these admirable mid-century goals. Already, the Washington Post re-

12 Experimentation to effect this is taking place at www.peaceinnovation.stanford.edu. 13

https://www.washingtonpost.com/washington-post-live/2021/08/10/future-evangelical-movement-with-russell-moore -phd/. Evangelical authority Moore asserts that older evangelicals are susceptible to misinformation and even to conspiracy theories. 
ports, ${ }^{14}$ some of our planet's regions have become too hot and humid for human survival. All this is to say, things will get worse before they get better.

Changing our personal lifestyles toward lighter carbon footprints will have a miniscule direct impact on climate change, compared to corporations' impacts. Our lifestyle changes are still valuable, though, not just for our personal satisfaction, but as a good example to those to whom we must reach out and initiate dialogue - and as reinforcement for those who already agree with us.

With luck, changes in views and behavior will cascade, as our outreach moves skeptical offspring of anti-environmentalists, and they in turn persuade their parents to vote to preserve the Earth for the next generations.

Author Contributions: Conceptualization, F.P.; methodology, F.P and R.T.; validation, L.R. and R.T.; writing - original draft preparation, writing, review and editing, F.P. All authors have read and agreed to the published version of the manuscript.

Fred Phillips is the 2017 Kondratieff Laureate, and Editor-in-Chief Emeritus of Technological Forecasting $\mathcal{E}$ Social Change. He is President of the thinktank/consultancy TANDO, Inc., www.tando.org

LaVonne Reimer is a lawyer and an education entrepreneur. She is active in the Mennonite church.

Rebecca Turner is a consulting psychologist. She is a Fellow of the American Psychological Association, and a Fellow of the Society of Consulting Psychology.

Funding: This research received no external funding.

Institutional Review Board Statement: Not applicable..

Conflicts of Interest: The authors declare no conflict of interest.

\section{References}

1. Natural Resources Defense Council. Available online: https://www.nrdc.org/onearth/climate-scientists-world-we-have-only-20-years-theres-no-turning-back (accessed on 12 October 2021).

2. The Washington Post. Available online: https://www.washingtonpost.com/science/2021/07/14/

moon-wobble-climate-change-could-mean-double-whammy-flooding-2030s-nasa-warns (accessed on 14 July 2021).

3. BBC. Available online: https://www.bbc.com/news/science-environment-48964736 (accessed on 24 July 2021).

4. Live Science. Available online: https://www.livescience.com/65633-climate-change-dooms-humans-by-2050.html (accessed on 4 June 2021).

5. Phillips, F. The Globalization Paradox. Technol. Forecast. Soc. Change. 2019, 143, 319-320.

6. Religion Unplugged. Available online: https://religionunplugged.com/news/2019/7/18/how-a-growing-evangelical-christian-community-in-latin-america-could-threa ten-democracy (accessed on 18 July 2021).

7. The Economist. Catholic Culture. The Economist, 2021, July 31, p.46

8. The Washington Post. Available online: https://www.washingtonpost.com/nation/2021/07/11/mercy-culture-church/ (accessed on 11 July 2021).

9. Business Insider. Available online:

https://www.businessinsider.com/apple-demands-employees-return-to-office-in-september-2021-6 (accessed on 30 June 2021).

10. Gallup Inc. Available online: https://news.gallup.com/poll/248027/americans-concerned-ever-global-warming.aspx (accessed on 25 March 2021).

11. Smart Cities Dive. Available online: https://www.smartcitiesdive.com/news/too-few-companies-advocate-for-climate-friendly-policies-despite-lofty-goal/603185/ (accessed on 13 July 2021).

12. The Washington Post. Available online: https://www.washingtonpost.com/politics/courts_law/supreme-court-cocoa-farms-africa-child-slavery/2021/06/17/295ab51e-b eed-11eb-83e3-0ca705a96ba4_story.html (accessed on 17 June 2021).

13. Levine, P. Night Vision. Bantam, 1991.

14. Price, G. Reality Testing; Down By Law Books, 2021.

14 https://washingtonpost.com/weather/2021/07/24/wet-bulb-temperature-extreme-heat/ 
15. MicCheck. Available online:

https://www.mic.com/p/these-6-countries-are-most-likely-to-survive-a-climate-change-caused-societal-collapse-82704326 (accessed on 3 August 2021).

16. The Washington Post. Available online: https://www.washingtonpost.com/magazine/2021/08/02/americas-hidden-crisis-power-place (accessed on 2 August 2021).

17. Robinson-Avila, K. Democratize Space? Not Restrictive Virgin Galactic. Albuquerque J. 2021, August 7, page A1.

18. Foreign Affairs. Available online: https://www.foreignaffairs.com/articles/united-states/2020-04-10/climate-club (accessed on May/June 2021).

19. Latané, B.; Nida, S. Ten years of research on group size and helping. Psychol. Bull. 1981, 89, 308 -324.

20. Simply Psychology. Available online: https://www.simplypsychology.org/bystander-effect.html (accessed on 17 June 2021 ).

21. National Public Radio. Available online: https://www.npr.org/2012/03/07/148125942/the-book-of-revelation-visions-prophecy-politics (accessed on 7 March 2021).

22. The Washington Post. Available online: https://www.washingtonpost.com/opinions/2021/06/25/war-truth-is-raging-not-everyone-recognizes-were-it/ (accessed on 25 June 2021).

23. Cooperrider, J.D.; Srivastva, S. Appreciative inquiry in organizational life. In Woodman, R. W. Pasmore, W.A., Eds.. Res. Organ. Change Dev. 1987, Vol. 1, Stamford, CT: JAI Press. pp. 129-169.

24. Brockman, J. What We Believe But Cannot Prove: Today's leading thinkers on science in the age of certainty, ed.; Harper Perennial, 2006.

25. Tajfel, H.; Billig, M.G.; Bundy, R.P.; Flament, C. Social categorization and intergroup behaviour. Eur. J. Soc. Psychol. 1971, 1 (2), 149-178. doi:10.1002/ejsp.2420010202.

26. Moscovici. S. Toward a theory of conversion behavior. In L. Berkowitz (Ed.), Adv. Exp. Soc. Psychol. 1980, Vol. 13, pp. 209-239. New York: Academic Press.

27. Moscovici, S.; Zavalloni, M. The group as a polarizer of attitudes. J. Pers. Soc. Psychol. 1969, 12, 125-135.

28. Michael, J.; Marquardt, H.; Leonard, S.; Freedman, A.M. Action Learning for Developing Leaders and Organizations: Principles, Strategies, and Cases. American Psychological Association. 2009, 1st edition.

29. National Geographic. Available online: https://www.nationalgeographic.org/article/we-could-resurrect-woolly-mammoth-heres-how/ (accessed on $10 \mathrm{July} 2021$ ).

30. The Peninsula Report. Available online: https://thepeninsulareport.com/2019/05/23/the-rise-of-evangelism-in-south-korea/ (accessed on 23 May 2019).

31. The Washington Post. Available online: https://www.washingtonpost.com/opinions/ 2021/07/16/sharing-the-wealth/ (accessed on 16 July 2021).

32. Anglin, SM. Do beliefs yield to evidence? Examining belief perseverance vs. change in response to congruent empirical findings. J. Exp. Soc. Psychol. 2019 May 1, 82, 176-99.

33. Keohane, J. The Power of Strangers. Random House, 2021.

34. The Guardian. Available online: https://www.theguardian.com/sustainable-business/2017/jul/10/100-fossil-fuel-companies-investors-responsible-71-global-emi ssions-cdp-study-climate-change (accessed on 10 July 2021).

35. 24/7 Wall Street. Available online: https://247wallst.com/special-report/2019/06/06/corporations-behind-the-most-ocean-pollution/ (accessed on 6 June 2021). 